\title{
Dextrose Equivalent Analysis of Acid Hydrolysed Corn and Cassava Starch Sourced from Ghana
}

\author{
Odum Bismark ${ }^{1,2}$, Owusu Kwaku Michael $^{2}$, Odoom Kwesi Justice ${ }^{1,2}$, Ebenezer Otoo ${ }^{1,3, \text {, }}$ \\ Norgbey Eyram ${ }^{4}$, Kwakye Danso Benjamin ${ }^{5}$ \\ ${ }^{1}$ College of Harbor, Coastal and Offshore Engineering, Hohai University, Nanjing, China \\ ${ }^{2}$ Department of Chemical Engineering, College of Engineering, Kwame Nkrumah University of Science and Technology, Kumasi, Ghana \\ ${ }^{3}$ Department of Crop Science, College of Agricultural and Natural Resources, Kwame Nkrumah University of Science and Technology, \\ Kumasi, Ghana \\ ${ }^{4}$ Department of Environmental Engineering, College of Environment, Hohai University, Nanjing, China \\ ${ }^{5}$ Department of Mathematics, College of Science, Hohai University, Nanjing, China
}

Email address:

ebenezerotoo@hhu.edu.cn(E. Otoo),glorys123@yahoo.com (E. Otoo)

*Corresponding author

\section{To cite this article:}

Odum Bismark, Owusu Kwaku Michael, Odoom Kwesi Justice, Ebenezer Otoo, Norgbey Eyram, Kwakye Danso Benjamin. Dextrose Equivalent Analysis of Acid Hydrolysed Corn and Cassava Starch Sourced from Ghana. Science Journal of Chemistry.

Vol. 9, No. 2, 2021, pp. 45-53. doi: 10.11648/j.sjc.20210902.12

Received: November 17, 2020; Accepted: December 14, 2020; Published: April 23, 2021

\begin{abstract}
The use of acid hydrolysis to convert starch into dextrose can be difficult and time-consuming. The process requires high acidic medium and temperature which tends to contaminate the end-product hydrolysate. Therefore, this research was carried out to obtain optimum conditions necessary to produce a high and quality Dextrose Equivalent by varying the initial starch concentration and acid volume. The mass of corn and cassava starch and the total hydrochloric acid volume used for the hydrolysis ranged from 100 to $400 \mathrm{~g}$ and 1-3 liters respectively. The results showed that the optimum conditions for hydrolyzing the two starch types to Dextrose were within a temperature range of $100^{\circ} \mathrm{C}-120^{\circ} \mathrm{C}, 12 \mathrm{w} / \mathrm{w} \%$ starch concentration, 4 atmospheric pressure and 30 minutes operating time. The optimum conditions produced a Dextrose Equivalent of $79.80 \%$ and $78.66 \%$ for cassava and corn starch respectively. The amount of dextrose produced in the process is a function of temperature, pressure, acid volume, operating time and initial starch concentration. Experimental results also confirmed an increase in $\mathrm{pH}$ of the hydrolysate with a temperature rise, and this influenced the Dextrose quality. The outcomes provided new findings to complement existing outcomes on how initial starch concentration and acid volume affect Dextrose Equivalent by acid-type hydrolysis.
\end{abstract}

Keywords: Hydrolysis, Dextrose Equivalent, Starch, Dextrose, Hydrolysate, Titration

\section{Introduction}

Hydrolysis of starch to low-molecular products such as glucose, starch nanoparticles and adhesives is widely applied in many industries including the sugar, spirits and textile industries, as well as in the brewing industry [1, 2]. Acid hydrolysis of starch can be employed to convert starch into dextrose [3]. The degree of hydrolysis is often attained by means of mineral acids ( $\mathrm{pH} 2)$ and high temperatures from $140-220^{\circ} \mathrm{C}$ [1]. Industrial processing of starch for commercial production of glucose syrup mainly involves the employment of mineral acids for starch hydrolysis before the advent of enzymes [4, 5]. The use of enzyme and acid-enzyme hydrolysis of starch is being applied in some industries [1, 6-8]. The use of enzyme for starch hydrolysis is an indispensable method. One difficulty in using this method is that the stability of the enzymes cannot be assured. In addition, the $\mathrm{pH}$ level and temperature play vital role in their stability [1]. The source of the enzyme also affects the mode of action, properties and the product of hydrolysis [7] making it difficult to regulate most times. Enzyme and acid-enzyme hydrolysis can be expensive and time consuming, and sometimes difficult to undertake especially when the enzymes are not well cultured [7]. 
Acid hydrolysis of starch has wide applications even though it produces unnecessary by-products which may contaminate the end-product hydrolysate as a result of the high thermal processing [1, 9-11]. However, the employment of intensive filtration and purification methods as well as careful regulation of the process eliminate contaminants [6]. This method can be monitored and regulated without much difficulty at optimum conditions. The challenge for production of dextrose by acid hydrolysis process is obtaining high quality and quantity of Dextrose. Dextrose (glucose) is very useful. It is therefore crucial to identify and measure the factors and how each affect starch hydrolysis [1].

Hydrolysis of starch is widely employed in many biological and industrial processes [12]. Corn and cassava starch are major industrial raw material and they are used for energy generation after conversion to bioethanol [13-16]. Acid hydrolysis method is used to explore the structure of starch granules $[11,14,17,18]$. It is also employed in structure modification of native starches by altering the functional properties such as the starch swelling, gelatinization, retrogradation, pasting and digestive properties of starch granules [18, 19-21]. Acid hydrolysis was used as a modification method for production of starch-based adhesives and thin boiling of starch which have wide applications in many industries [13, 14, 18, 22-29].

The kinetics of starch hydrolysis is often monitored in two different ways. It includes insoluble residues and soluble sugar present in solution [2]. A two-stage hydrolysis pattern was observed by most researchers which involved a fast-initial rate followed by a slower rate $[12,14,17,29,30$, 32-36]. The relatively fast initial rate corresponded to amorphous regions of granules which are more prone to chemical hydrolysis $[12,14,30]$. The slow process was due to simultaneous hydrolysis of amorphous and crystalline starch regions $[17,19]$. The insoluble residue mostly comprises of crystalline parts of amylopectin which are acid-resistant [2, 21, 27]. With this knowledge, in recent years, research efforts are employed on using acid hydrolysis as one modification method to alter the structural and functional properties of native starch structure for wider applications of starch $[13,31]$. However, previous researches conducted have not provided a detailed results and information that explicitly explains how starch concentration and acid volume each affects Dextrose Equivalent (DE). Therefore, the present work investigated two different starches (corn and cassava starch) as model materials to identify and understand how the variation in acid volume and initial starch concentration affects the DE yield through acid hydrolysis. The effectiveness and efficiency of acid-enzyme and enzymatic hydrolysis [1, 4-6, 37-43] was also compared to acid hydrolysis.

\section{Materials and Methods}

\subsection{Material and Samples}

Carbohydrate extracts of corn and cassava starch were prepared in the laboratory from maize grains (Zea Mays) and cassava root tubers (Manihot Escalenta Crantz) respectively. The crop variety from which the corn and cassava starch was extracted is "Obaatanpa" and "CRI Essam Bankye" respectively. These varieties were sourced from Ghana [44].

Stock concentrations of hydrochloric acid, sodium carbonate, benedict reagent, standard glucose, activated carbon and all other apparatus used for the research were accessed from the Chemical Engineering and Chemistry Research Laboratories of Kwame Nkrumah University of Science and Technology, Kumasi Ghana. The samples are well described in Table 1 .

Table 1. Sample conditions, labels and their descriptions

\begin{tabular}{llll}
\hline Sample Label & Sample Description & $\begin{array}{l}\text { Sample concentrations } \\
\text { (w/w \%) }\end{array}$ & $\begin{array}{l}\text { Density of hydrolyzed } \\
\text { solution mixture, g/ml }\end{array}$ \\
\hline $\mathrm{HS} \frac{100 \mathrm{C}}{1000}$ & $100 \mathrm{~g}$ of cassava starch mixed with $1000 \mathrm{ml}$ of $0.1 \mathrm{M} \mathrm{HCl}$ & 9.09 & 1.0470 \\
$\mathrm{HS} \frac{100 \mathrm{C}}{1500}$ & $100 \mathrm{~g}$ of cassava starch mixed with $1500 \mathrm{ml}$ of $0.1 \mathrm{M} \mathrm{HCl}$ & 6.25 & 1.0650 \\
$\mathrm{HS} \frac{100 \mathrm{C}}{2000}$ & $100 \mathrm{~g}$ of cassava starch mixed with $2000 \mathrm{ml}$ of $0.1 \mathrm{M} \mathrm{HCl}$ & 4.76 & 1.0450 \\
$\mathrm{HS} \frac{200 \mathrm{C}}{1000}$ & $200 \mathrm{~g}$ of cassava starch mixed with $1000 \mathrm{ml}$ of $0.1 \mathrm{M} \mathrm{HCl}$ & 16.67 & 1.0730 \\
$\mathrm{HS} \frac{200 \mathrm{C}}{1500}$ & $200 \mathrm{~g}$ of cassava starch mixed with $1500 \mathrm{ml}$ of $0.1 \mathrm{M} \mathrm{HCl}$ & 11.76 & 1.0767 \\
$\mathrm{HS}$ & $200 \mathrm{~g}$ of cassava starch mixed with $2000 \mathrm{ml}$ of $0.1 \mathrm{M} \mathrm{HCl}$ & 9.09 & 1.0520 \\
$\mathrm{HS}$ & $200 \mathrm{~g}$ of corn starch mixed with $1500 \mathrm{ml}$ of $0.1 \mathrm{M} \mathrm{HCl}$ & 11.76 & 1.0767 \\
$\mathrm{HS}$ & $400 \mathrm{~g}$ of corn starch mixed with $3000 \mathrm{ml}$ of $0.1 \mathrm{M} \mathrm{HCl}$ & 11.76 & 1.1013 \\
\hline
\end{tabular}

\subsection{Experimental Procedures of Acid Hydrolysis}

\subsubsection{Acid Hydrolysis of Corn and Cassava Starch}

Different volumes (1 liter, 1.5 liters, 2 liters and 3 liters) of

$0.1 \mathrm{M} \mathrm{HCl}$ were prepared from stock concentration of $\mathrm{HCl}$.

During the lab experiment; taking sample $\mathrm{HS} \frac{100 C}{1000}$ for

example, $100 \mathrm{~g}$ of cassava starch was initially weighed and then transferred into a clean pressure cooker (autoclave). A diluted solution of 1 liter was prepared $0.1 \mathrm{M} \mathrm{HCl}$ and mixed with the starch within the autoclave and constantly stirred until a homogenous solution mixture was formed. The autoclave (containing the starch mixture) was placed on a heated hot plate. The starch mixture was heated whilst stirring (on agitator at $400 \mathrm{rpm}$ ) until it gelatinized. Careful heating and continuous stirring were necessary in order to obtain fine starch gel. The gelatinized starch mixture was further heated 
for 30 minutes within a temperature range of $\left(100^{\circ} \mathrm{C}-120^{\circ} \mathrm{C}\right)$ at pressure $4 \mathrm{~atm}$ and the starch was converted into dextrose (glucose). The autoclave was tightly covered at this stage to prevent excessive heat loss and maintain constant pressure. After 30 minutes operating time, the autoclave was opened and the content (hydrolysate) was allowed to cool down to a normal room temperature. The $\mathrm{pH}$ of the hydrolysate was slightly acidic. The above procedures were repeated for each sample with variation in starch weight and volume of acid as described in Table 1.

\subsubsection{Processing of Hydrolyzed Starch}

The remaining hydrochloric acid $(\mathrm{HCl})$ in the hydrolysate (glucose slurry) was neutralized with calculated amounts of sodium carbonate $\left(\mathrm{Na}_{2} \mathrm{CO}_{3}\right)$, as illustrated in Figure 1. Taking sample $\mathrm{HS} \frac{100 C}{1500}$ for instance, the hydrolysate was neutralized by adding $5.679 \mathrm{~g}$ of sodium carbonate $\left(\mathrm{Na}_{2} \mathrm{CO}_{3}\right)$ granules to adjust the $\mathrm{pH}$ to about 6.34 at $23.1^{\circ} \mathrm{C}$. The quantity of sodium carbonate needed to completely neutralize the $\mathrm{HCl}$ increased with an increase in $\mathrm{HCl}$ volume. Addition of $\mathrm{Na}_{2} \mathrm{CO}_{3}$ to the hydrolysate was characterized by effervescent gas due to escape of carbon dioxide. The production of carbon dioxide is shown by the equations below;

$$
\begin{aligned}
2 \mathrm{HCl}(\mathrm{aq})+ & \mathrm{Na}_{2} \mathrm{CO}_{3}(\mathrm{~s}) \rightarrow 2 \mathrm{NaCl}(\mathrm{s})+\mathrm{H}_{2} \mathrm{CO}_{3}(\mathrm{aq}) \\
\mathrm{H}_{2} \mathrm{CO}_{3}(\mathrm{aq}) & \rightarrow \mathrm{H}_{2} \mathrm{O}(\mathrm{l})+\mathrm{CO}_{2}(\mathrm{~g})
\end{aligned}
$$

Sodium chloride and carbonic acid were formed when hydrochloric acid reacted with sodium carbonate as shown is equation 1 above. Carbonic acid is unstable at room temperature, therefore it decomposed into water and carbon dioxide as indicated in equation 2. The sodium chloride was refined and eliminated from the solution. Solid impurities like precipitated protein and coagulated fats hydrolysis contained in the hydrolysate were centrifugal separation and surface adsorption using $20 \mathrm{~g}$ of Activated Carbon. The quality of the dextrose was affected by the efficiency of the refining and purification methods. The impurities largely depended on the starch source [6]. The starch used for the experiment contained low protein content. The hydrolysate was filtered through a filter placed on a funnel and connected to a vacuum pump to create vacuum for suction of the solution through the pores of the filter paper into a clean, dried and empty container. To obtain more concentrated glucose slurry; the hydrolysate was heated in an evaporation unit (continuous heat exchangers) under controlled temperature.

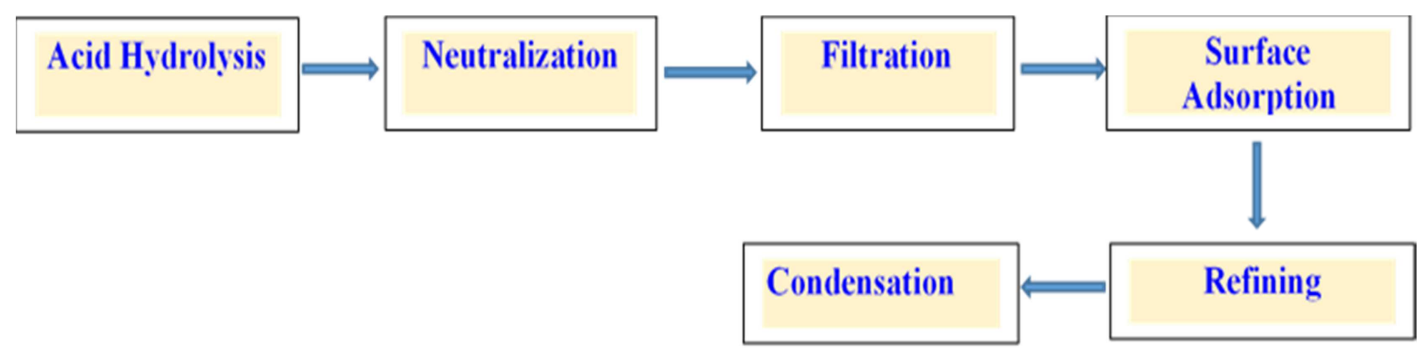

Figure 1. Block diagram showing the general steps employed in the acid hydrolysis of corn and cassava starch.

\subsection{Titration Method}

\subsubsection{Titration of Hydrolysate}

Titration of end product of corn and cassava starch hydrolysis was carried out to determine the quantity of reducing sugars (dextrose) produced by using Lane-Eynon titration method $[45,46] .10 \mathrm{~g}$ of hydrolyzed starch sample ( HS $\frac{200 C}{1500}$ ); hydrolysate, was diluted with deionized water to $100 \mathrm{ml}$ dilute which contains dextrose (glucose). The hydrolysate herein referred as the analyte was transferred into a $50 \mathrm{ml}$ calibrated burette, and titrated against a known amount $(20 \mathrm{ml})$ of boiling benedict solution (copper sulphate solution); titrant, contained in Erlenmeyer flask with methylene blue as indicator. The indicator changed colour from blue to light green once all the copper sulphate in solution reacted with the glucose. The titration was ceased when a colour change was observed. The titration was repeated thrice and the average titre value (volume of glucose) was recorded. These procedures were repeated for each starch sample. However, the reaction between the glucose and the benedict solution was not stoichiometric, therefore a calibration curve was scrutinized whiles further titrations were carried out with series of known concentrations of standard glucose solution.

\subsubsection{Procedures for Titration of Standard Glucose Against Benedict Solution}

Different concentrations of standard glucose solution (5 $\mathrm{w} / \mathrm{w} \%, 4.5 \mathrm{w} / \mathrm{w} \%, 4.0 \mathrm{w} / \mathrm{w} \%, 3.5 \mathrm{w} / \mathrm{w} \%, 3.0 \mathrm{w} / \mathrm{w} \%, 2.5$ $\mathrm{w} / \mathrm{w} \%, 2.0 \mathrm{w} / \mathrm{w} \%, 1.5 \mathrm{w} / \mathrm{w} \%$ ) were prepared. The density and mass of each homogenous standard glucose concentrations was determined and recorded in Table 2. $100 \mathrm{ml}$ of dilute standardized benedict solution was prepared using a benedict reagent of stock concentration. $20 \mathrm{ml}$ of dilute benedict solution (as titrant) was pipetted and transferred into a $50 \mathrm{ml}$ beaker and placed in a hot water bath maintained at $90^{\circ} \mathrm{C}$ for 2 minutes. $5 \mathrm{w} / \mathrm{w} \%$ concentration of prepared standard glucose solution was transferred into a $50 \mathrm{ml}$ burette, and this was titrated against $20 \mathrm{ml}$ warmed benedict solution whilst it was still in hot water bath until the blue colour changed to light green. The titration was repeated for the same $5 \mathrm{w} / \mathrm{w} \%$ standard glucose solution concentration and the average titre value was recorded. The titration process was repeated for each of the standard glucose concentration. 
Table 2. Titration results of standard glucose solution against benedict solution.

\begin{tabular}{llll}
\hline Weight \% concentration of glucose standard solution & Density of the solution $(\mathbf{g} / \mathbf{m l})$ & Average tire value $(\mathbf{m l})$ & Mass of standard glucose $(\mathbf{g})$ \\
\hline 5 & 1.020 & 0.30 & 0.0153 \\
4.5 & 1.013 & 0.90 & 0.0210 \\
4 & 1.000 & 1.40 & 0.0381 \\
3.5 & 1.008 & 1.75 & 0.0439 \\
3 & 1.008 & 2.55 & 0.0446 \\
2.5 & 1.002 & 3.15 & 0.0449 \\
2 & 1.004 & 4.40 & 0.0456 \\
1.5 & 1.009 & 5.30 & 0.0460 \\
\hline
\end{tabular}

Consistent average mass of standard glucose $=\frac{0.0439+0.0446+0.0449+0.0456+0.0460}{5}=0.045 \mathrm{~g}$

\section{Results and Discussion}

\subsection{Titration of Standard Glucose Solution Against Benedict Solution}

Methylene blue indicator was used in the titration to mark the end-point of the titration with a colour change of benedict solution. The reason is because glucose solution in the presence of benedict solution resulted in a colour change from blue to light green. This was due to the conversion of $\mathrm{Cu}^{2+}$ to $\mathrm{Cu}^{+}$ present in the solution at a temperature between $90^{\circ} \mathrm{C}-98^{\circ} \mathrm{C}$.

From the titration results indicated in Figure 2, it was observed that the amount of standard glucose (titre value) needed to 'neutralize' the benedict solution increased as the concentration of the standard glucose decreased. This observation was due to a decrease in the amount of glucose molecules per the volume of standard glucose solution. When the concentration of standard glucose solution decrease from 5 to $1.5 \mathrm{w} / \mathrm{w} \%$, more of the glucose was required to 'neutralize' the same $20 \mathrm{ml}$ benedict solution.

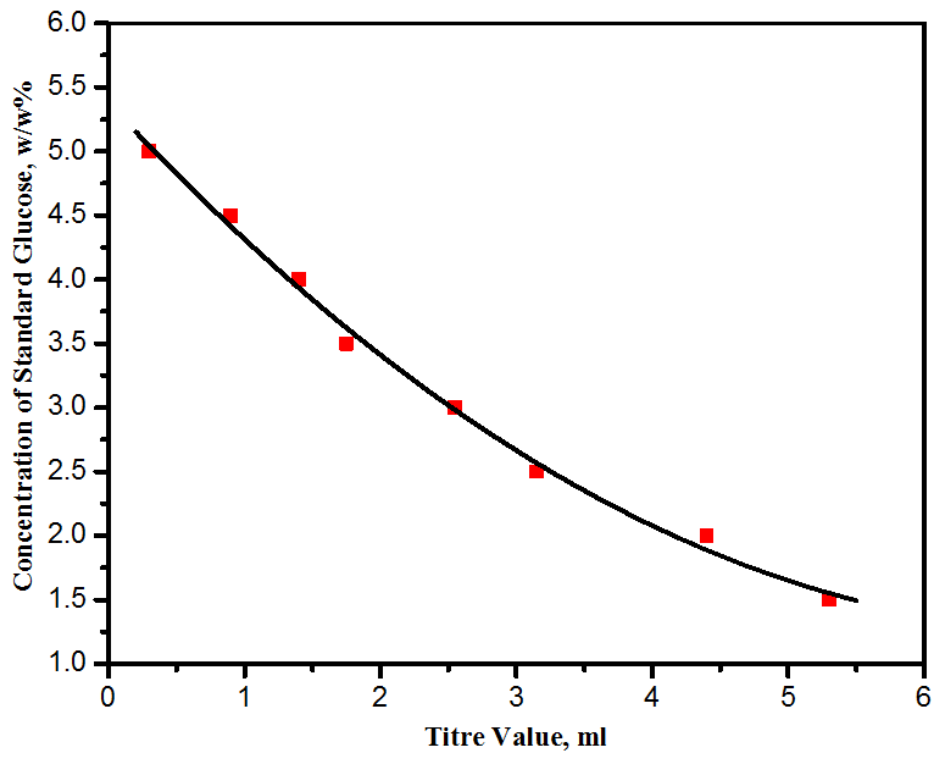

Figure 2. Titration of standard glucose solution (w/w\%) against warmed $20 \mathrm{ml}$ benedict solution, titre value recorded in ml.

\subsection{Titration of Hydrolyzed Starch Samples Against Benedict Solution}

After hydrolysis of sample $\mathrm{HS} \frac{100 C}{1000}, \mathrm{HS} \frac{100 C}{1500}$ and HS $\frac{100 C}{2000}$, different titre values were observed when each of these samples was titrated against benedict solution. An increase in the volume of $0.1 \mathrm{M} \mathrm{HCl}$ in the samples resulted in a decrease in the titre values recorded. This implies that as the volume of $0.1 \mathrm{M} \mathrm{HCl}$ was increased, more of the cassava starch was hydrolyzed into glucose hence a small volume of the hydrolysate was necessary to cause benedict solution to change color and vice versa. Therefore, a decreasing amount of each glucose slurry was enough to neutralize equal amount of benedict solution (Figure 3). The conclusion was that an increase in acid volume produced more glucose even when the mass of starch samples was maintained constant. The same conclusion was drawn for corn samples ( $\mathrm{HS} \frac{200 M}{1000}$, HS $\frac{200 M}{1500}$ and HS $\frac{200 M}{2000}$ ). From the Table 3, it was observed that the volume of glucose slurry (titre values) decreased from $8.35 \mathrm{ml}$ to $1.75 \mathrm{ml}$ with an increase in acid $(0.1 \mathrm{M} \mathrm{HCl})$ volume from 1 liter to 2 liters. 
Table 3. Total acid volume effect on the amount of dextrose produced following acid hydrolysis.

\begin{tabular}{lll}
\hline $\begin{array}{l}\text { Volume of stock concentrations of } \\
\text { HCl, } \mathbf{~ m l}\end{array}$ & $\begin{array}{l}\text { Volumes of diluted } \mathbf{0 . 1 M ~ H C l ~ u s e d ~ f o r ~ a c i d ~} \\
\text { hydrolysis, liter(s) }\end{array}$ & $\begin{array}{l}\text { Volume of hydrolyzed HS } \frac{\mathbf{1 0 0 C}}{\mathbf{1 0 0 0}}, \mathrm{HS}_{\mathbf{1 5 0 0}}^{\mathbf{1 0 0 C}} \text { and HS } \frac{\mathbf{1 0 0 C}}{\mathbf{2 0 0 0}} \text { samples } \\
\text { needed to cause color change of benedict solution, ml }\end{array}$ \\
\hline 9.83 & 1 & 8.35 \\
14.7 & 1.5 & 2.00 \\
19.7 & 2 & 1.75 \\
\hline
\end{tabular}

The reason was that an increase in the total volume of acid resulted in an increase in the amount of glycosidic bonds in starch molecules which were broken down to produce the glucose. The glycosidic bonds in starch polysaccharides needed to be broken down into monosaccharides in order to obtain the simple sugars (dextrose). The more the starch was converted into glucose after hydrolysis the smaller the titre value needed to neutralize the benedict solution. This observation was expected because compared to results of standard glucose titration with benedict solution, the total volume of standard glucose (titre value) needed to neutralize the same volume of benedict solution increased with a decrease in the concentrations of glucose standard. Similar observations and conclusions were drawn for sample $\mathrm{HS} \frac{200 C}{1000}, \mathrm{HS} \frac{200 C}{1500}, \mathrm{HS} \frac{200 C}{2000}$ as well as sample $\mathrm{HS} \frac{200 M}{1000}$, $\mathrm{HS} \frac{200 M}{1500}$ and $\mathrm{HS} \frac{200 M}{2000}$.

When $200 \mathrm{~g}$ of cassava starch was used with varying volumes of $\mathrm{HCl}$ solution, the results obtained from the titration process indicated a decrease in the titre values of glucose slurry from $2.7 \mathrm{ml}$ to $0.6 \mathrm{ml}$. The two smallest titre values $(0.63 \mathrm{ml}$ and $0.60 \mathrm{ml})$ was recorded for sample $\mathrm{HS} \frac{200 M}{1500}$ and $\mathrm{HS} \frac{200 C}{1500}$ (approximately $12 \mathrm{w} / \mathrm{w} \%$ initial corn and cassava starch concentrations respectively) as indicated in Figure 3 and Figure 4. These results demonstrated that the local optimum condition for high yield of dextrose through acid hydrolysis was at $12 \mathrm{w} / \mathrm{w} \%$ initial cassava and corn starch concentrations, initial $\mathrm{pH}$ value of 2 , 30 minutes operating time, 4 atmospheric pressure and within a temperature range of $100^{\circ} \mathrm{C}-120^{\circ} \mathrm{C}$. The acid concentration, the $\mathrm{pH}$ and duration of hydrolysis also had significant effect on the DE $[1,14]$. For commercial production of dextrose from cassava and corn starch, a scale-up under the same conditions can be considered. A hydrolysate with high DE value contained significant (large) amount of glucose and vice versa. Hydrolysis of starch under optimum conditions in this research produced high quantity and quality dextrose which may also serve as raw material for further conversion into different kinds of chemicals, such as citric acid, fumaric acid, lactic acid and end-product ethanol [47].

\subsection{DE Computation}

The degree of hydrolysis was measured as an increase in the content of reducing sugars $[42,48]$. The DE indicates the extent to which starch was hydrolyzed into simple sugar (glucose) following starch hydrolysis. In other words, Dextrose Equivalent denotes the degree of hydrolysis of starch; and by extension how much glucose was obtained. This parameter was determined analytically by the formula; Dextrose Equivalent (DE)

$$
=\frac{\text { Reducing sugar (expressed as glucose) }}{\text { Total carbohydrates }} \times 100 \quad[48,49] \text {. }
$$

The average mass of standard glucose $(0.045 \mathrm{~g})$ per the mass of each hydrolyzed starch sample expressed as a percentage accounted for the DE value of a particular sample. Taking sample HS $\frac{200 C}{1500}$ for example; the mass and density of the hydrolyzed sample concentration was $10 \mathrm{~g}$ and 1.064 $\mathrm{g} / \mathrm{ml}$ respectively. Therefore,

The volume of hydrolyzed sample $\left(\mathrm{HS} \frac{200 C}{1500}\right)=\frac{\text { Mass of concentrated sugar }}{\text { Density of concentrated sugar }}=\frac{10}{1.064}=9.398 \mathrm{ml}$.

$$
\text { The dilution factor }=\frac{\text { Total volume of hyrolyzed sample after dilution }}{\text { Volume of concentrated sample }}=\frac{100 \mathrm{ml}}{9.398 \mathrm{ml}}=10.64
$$

Mass of dilute sample solution $=$ Volume $x$ Density of diluted sample. The density and volume (titre value) of diluted sample was approximate $1 \mathrm{~g} / \mathrm{ml}$ and $0.6 \mathrm{ml}$.

$$
\text { Dextrose Equivalent of sample }\left(\mathrm{HS} \frac{200 C}{1500}\right)=\frac{\text { Mass of standard glucose }}{\left(\frac{\text { Mass of diluted sample solution }}{\text { Dilution factor }}\right)} \times 100=\frac{0.045}{\left(\frac{1 \times 0.6}{10.64}\right)} \times 100=79.8 \%
$$

\subsection{Analysis of DE Values}

The highest DE recorded at the local optimum conditions for acid hydrolysis of corn and cassava starch was $78.7 \%$ and
$79.8 \%$ respectively. The DE values demonstrated that the two starch sources yielded some amount of reducing sugars. Different starch sources often produce varied amount of DE even under the same conditions. This was due to the fact that 
different starch sources contained varying quantity of constituents such as protein, fat or lipids, phosphorus and moisture content which had some impact on the DE.

From Table 4, it was observed that, when $100 \mathrm{~g}$ of starch was maintained, and the volume of $0.1 \mathrm{M} \mathrm{HCl}$ increased by $500 \mathrm{ml}$, the amount of dextrose produced, increased from $5.51 \%$ to $26.87 \%$. When 1 litre and 1.5 litres of $0.1 \mathrm{M} \mathrm{HCl}$ was maintained whiles the amount of starch was increased by $100 \mathrm{~g}$ respectively, the DE increased drastically (approximately tripled). For example, consider sample $\mathrm{HS} \frac{100 C}{1000}$ with $\mathrm{DE}=5.51 \%$ compared to sample $\mathrm{HS} \frac{200 C}{1000}$ with $\mathrm{DE}=17.88 \%$, as well as sample $\mathrm{HS} \frac{100 C}{1500}$ with $\mathrm{DE}=$
$23.27 \%$ compared to sample $\mathrm{HS} \frac{200 C}{1500}$ with $\mathrm{DE}=79.80 \%$. Meanwhile, when the mass of cassava starch and the volume of $\mathrm{HCl}$ was increased simultaneously (i.e. $100 \mathrm{~g}$ and $1000 \mathrm{ml}$ increment in cassava starch and $0.1 \mathrm{M} \mathrm{HCl}$ respectively or in other words constant $9.09 \mathrm{w} / \mathrm{w} \%$ sample concentration) the DE approximately doubled. However, the DE recorded for these initial starch concentrations were very small. For instance, sample $\mathrm{HS} \frac{100 C}{1000}$ with $\mathrm{DE}=5.51 \%$ compared to sample $\mathrm{HS} \frac{200 C}{2000}$ with $\mathrm{DE}=11.01 \%$. These mixture of samples (9.09 w/w \% starch-HCl concentration) yielded small amount of glucose.

Table 4. Illustration of computed DE values of sample solutions.

\begin{tabular}{|c|c|c|c|}
\hline Sample Label & $\begin{array}{l}\text { Volume of hydrolyzed sample needed to neutralize } \\
\text { benedict solution, ml }\end{array}$ & $\begin{array}{l}\text { Sample } w / w \% \text { solution } \\
\text { concentration }\end{array}$ & $\begin{array}{l}\text { Dextrose Equivalent } \\
\text { (DE), \% }\end{array}$ \\
\hline $\mathrm{HS} \frac{100 \mathrm{C}}{1000}$ & 8.35 & 9.09 & 5.51 \\
\hline $\mathrm{HS} \frac{100 \mathrm{C}}{1500}$ & 2.00 & 6.25 & 23.27 \\
\hline $\mathrm{HS} \frac{100 \mathrm{C}}{2000}$ & 1.75 & 4.76 & 26.87 \\
\hline $\mathrm{HS} \frac{200 \mathrm{C}}{1000}$ & 2.70 & 16.67 & 17.88 \\
\hline $\mathrm{HS} \frac{200 \mathrm{C}}{1500}$ & 0.60 & 11.76 & 79.80 \\
\hline $\mathrm{HS}_{2000} \frac{200 \mathrm{C}}{200}$ & 4.3 & 9.09 & 11.01 \\
\hline $\mathrm{HS}^{200 \mathrm{M}} \frac{1500}{1500}$ & 0.63 & 11.76 & 78.66 \\
\hline
\end{tabular}

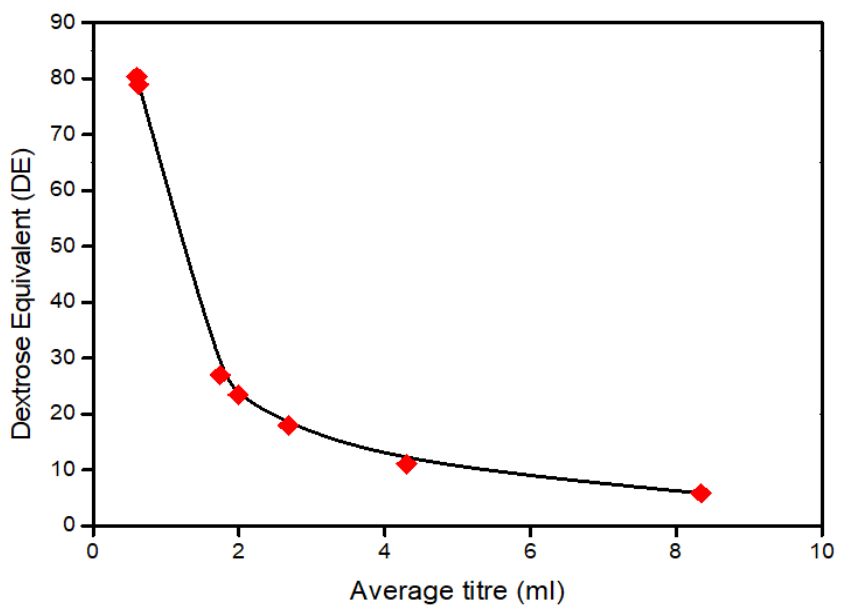

Figure 3. Demonstration of the degree at which glycosidic bonds cleave to produce glucose (Dextrose Equivalent) which influenced the volume of hydrolysed starch necessary to neutralize $20 \mathrm{ml}$ of benedict solution. The smaller the average titre value the larger the amount of glucose produced in the hydrolysed starch samples.

The highest DE was recorded when the increase in the quantity of both starch types (including selected samples indicated below) and $0.1 \mathrm{M} \mathrm{HCl}$ were at $100 \mathrm{~g}$ and $500 \mathrm{ml}$ intervals respectively. Therefore, a comparison drawn between sample $\mathrm{HS} \frac{100 C}{1000}$ with $\mathrm{DE}=5.51 \%$ to sample $\mathrm{HS} \frac{200 C}{1500}$ with $\mathrm{DE}=79.80 \%$ as well as sample $\mathrm{HS} \frac{100 M}{1000}$ with $\mathrm{DE}=6.62 \%$ to sample $\mathrm{HS} \frac{200 M}{1500}$ with $\mathrm{DE}=78.66 \%$ proved true. However, some previous researches showed that higher dextrose yield can be obtained when acid hydrolysis is proceeded by enzyme hydrolysis using saccharifying enzyme. Saccharifying enzyme was proven to produces a higher yield of reducing sugar compared to liquefying enzyme $[6,7]$.

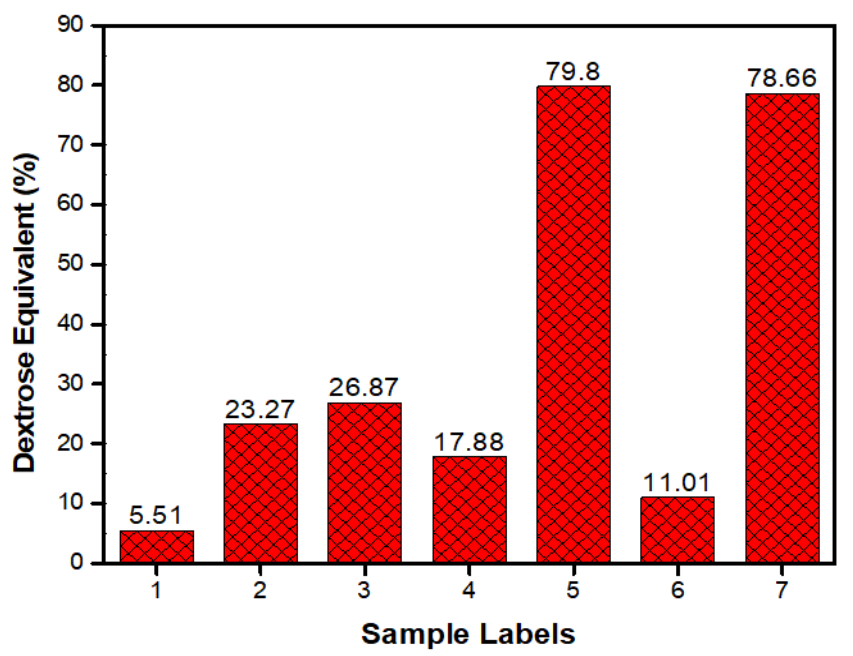

Figure 4. The Dextrose Equivalent (DE) of sample hydrolysates following acid hydrolysis of corn and cassava starch into dextrose.

\section{5. pH Variation with Temperature Change}

The effect of $\mathrm{pH}$ under conditions of temperature variation on the DE was scrutinized. Therefore, considering the $\mathrm{pH}$ of 
sample $\mathrm{HS} \frac{300 M}{4000}$ (Figure 5) for example, during hydrolysis the $\mathrm{pH}$ decreased as the temperature was raised. Different $\mathrm{pH}$ values were recorded for the starch reaction mixture at different temperatures. One disadvantage of this observation was that, the acidity of the hydrolyzed starch tends to increase with temperature. The increase in $\mathrm{pH}$ meant increase in acid content and this was eliminated through neutralization reaction with calculated amount of $\mathrm{Na}_{2} \mathrm{CO}_{3}$ for each sample. One of the end products which was eliminated following the neutralization process was $\mathrm{NaCl}$. Therefore, using optimum $\mathrm{pH}$, and especially temperature regulation was a key factor considered and controlled during the process to produce high quality and quantity of dextrose.

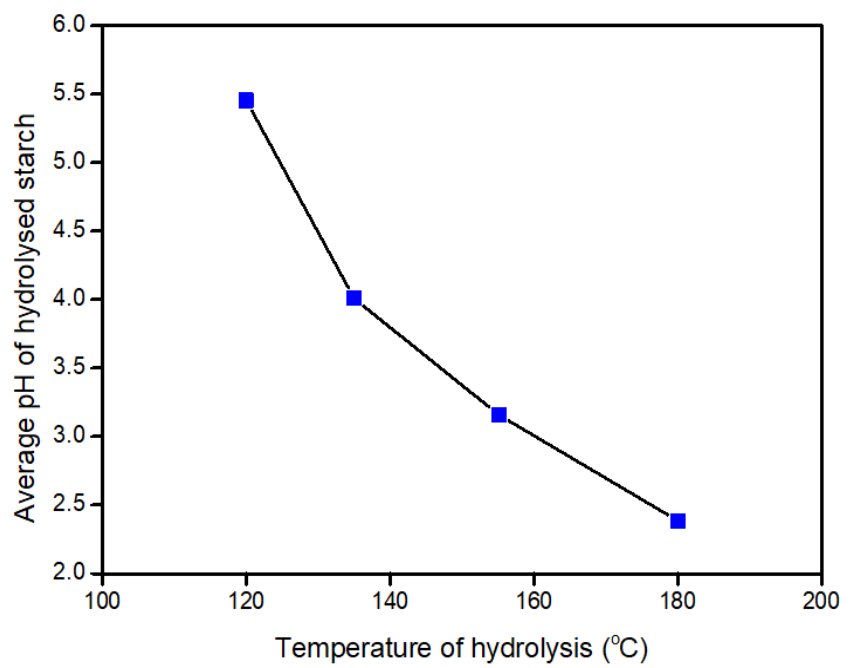

Figure 5. The plot demonstrates the effect of temperature on the $\mathrm{pH}$ of starch undergoing acid hydrolysis. An increase in temperature causes a rise in the average $\mathrm{pH}$ of hydrolyzed starch sample.

\section{Conclusion}

This study was conducted to determine the optimum condition with focus on the initial concentration of starch-acid mixture. Results demonstrated that the quality and quantity of dextrose produced following acid hydrolysis is significantly affected by the acid volume and initial starch concentration. The optimum conditions obtained was $12 \mathrm{w} / \mathrm{w} \%$ initial starch concentration (200 grams of corn/cassava in 1.5 litres of $0.1 \mathrm{M} \mathrm{HCl} \mathrm{mixture)}$ which yielded high DE after 30 minutes operating time and within a temperature range of $100^{\circ} \mathrm{C}-120^{\circ} \mathrm{C}$ and at a pressure of $4 \mathrm{~atm}$. One other observation from the process showed that the source of the starch has effect on the DE. However, this effect was not significant for corn and cassava compared to other factors such as the volume of acid and mass of starch used. Nevertheless, different starch sources constitute different physical and chemical properties due to different compositions and or proportions of amylose and amylopectin [31, 50] as well as the presence of constituents like protein, lipid, phosphorus and moisture $[51,52]$. The results showed that at optimum conditions as indicated, approximate DE values of $79.80 \%$ and $78.66 \%$ was obtained for cassava and corn starch respectively.

Analysis of results and reviews show that the quality and quantity of dextrose produced may be affected by a number of factors which includes the process temperature, pressure, acid volume, operating time and initial starch concentration. The focus of this study reveals, under the stated conditions, that the initial starch concentration (taking into consideration the mixing ratio of acid volume and the dry weight of starch sample) is a significant factor to consider for a high quantity and quality dextrose yield during acid hydrolyses. It is also recommended that other conditions be extensively exploited for an in-depth understanding in the quest to improve quality yield with the process.

\section{References}

[1] Yankov, D., Dobreva, V., Beschkov V. and Emanuilova, E. (1986). Study of optimum conditions and kinetics of starch hydrolysis by means of thermostable $\alpha$-amylase, Journal of Enzyme and Microbial Technology. Elsevier, 8 (11), 665-667.

[2] Wang, S. and Copeland, L. (2015). Effect of acid hydrolysis on starch structure and functionality: a review. Critical reviews in food science and nutrition.

[3] Scott, J. R., Ball, D. W. and Hill, J. W. (2011). Introduction to Chemistry, General Organic and Biological Carbohydrate.

[4] Howling, D. (1989). Mechanisms of Starch Enzymolysis. Journal of International Biodeterioration. 25, 15-19.

[5] Tester, R. F., Qi, X. and Karkalas, J. (2006). Hydrolysis of native starches with amylases. Animal Feed Science and Technology, 130 (1-2), 39-54.

[6] Whistler, R. L., and Paschal, E. F. (1965). Starch chemistry and technology. Vol. 2, New York, Academic Press.

[7] Kanlaya, Y. and Jirasak, K. (2004). A Study of Optimal Conditions for Reducing Sugars Production from Cassava Peels by Diluted Acid and Enzyme. Journal of Nat. Sci. 38, 29-35.

[8] Singh, J., Kaur, L. and McCarthy, O. J. (2007). Factors influencing the physico-chemical, morphological, thermal and rheological properties of some chemically modified starches for food applications - A review. Food Hydrocolloid. 21, 1-22.

[9] Palacios-Fonseca, A. J., et al (2013) Effect of the alkaline and acid treatments on the physicochemical properties of corn starch. CyTA - Journal of Food, 11 (sup1), 67-74.

[10] Liu, G., et al (2017). Structure, functionality and applications of debranched starch: A review. Trends in Food Science and Technology.

[11] Xing, J., et al (2017). LWT - Food Science and Technology Heat-moisture treatment and acid hydrolysis of corn starch in different sequences, LWT - Food Science and Technology. Elsevier Ltd, 79, 369-392.

[12] Hun, J., Han, D. and Kim, J. (2017). Food Hydrocolloids Effect of heat-moisture treatment under mildly acidic condition on fragmentation of waxy maize starch granules into nanoparticles. Food hydrocolloids. Elsevier Ltd, 63, 59-66. 
[13] Chung, H., Hoover, R. and Liu, Q. (2009). International Journal of Biological Macromolecules The impact of single and dual hydrothermal modifications on the molecular structure and physicochemical properties of normal corn starch. 44, 203210.

[14] Chen, P., et al (2017). Food Hydrocolloids Effect of acid hydrolysis on the multi-scale structure change of starch with different amylose content. Food hydrocolloids. Elsevier Ltd, 69, 359-368.

[15] Burrell, M. M. (2003). Starch: the need for improved quality or quantity-an overview. J. Exp. Bot. 54, 451-456.

[16] Balat, M., Balat, H. and Öz, C. (2008). Progress in bioethanol processing. Prog. Energy. Combust. Sci. 34, 551-573.

[17] Wang, S. J., Blazek, J., Gilbert, E. P. and Copeland, L. (2012). New insights on the mechanism of acid degradation of pea starch. Carbohydrate Polymers. Elsevier Ltd., 87 (3), 19411949.

[18] Wang, Y., et al (2017). Effects of different durations of acid hydrolysis on the properties of starch-based wood adhesive. International Journal of Biological Macromolecules, 103, 819828.

[19] Hoover, R. (2000). Acid-Treated Starches Acid-treated Starches. Food Reviews International, 16 (3) (2000), 369-392.

[20] $\mathrm{Hu}, \mathrm{X}$., et al (2014). Food Hydrocolloids Hydrolysis process of normal rice starch by 1-butanol e hydrochloric acid. Food hydrocolloids. Elsevier Ltd, 41, 27-32.

[21] Utrilla-coello, R. G., et al (2014). Acid hydrolysis of native corn starch: Morphology, crystallinity, rheological and thermal properties. Carbohydrate Polymers. Elsevier Ltd., 103, 596602 .

[22] Omojola, M. O., Manu, N. and Thomas, S. A. (2011). Effect of acid hydrolysis on the physicochemical properties of cola starch. Afr. J. of Pure Appl. Chem. 5 (9), 307-315.

[23] Gao, J., Vasanthan, T., Hoover, R. and Li, J. (2012). Structural modification of waxy, regular, and high-amylose maize and hulless barley starches on partial acid hydrolysis and their impact on physicochemical properties and chemical modification. Starch/Stärke.

[24] John, J. K., Raja, K. C. M., Rani, S., Moorthy, S. N. and Eliasson, A. (2002). Properties of arrowroot starch treated with aqueous $\mathrm{HCl}$ at ambient temperature. J. Food Sci. 67, 10-14.

[25] Nagahata, Y., Kobayashi, I. and Goto, M. (2013). The formation of resistant starch during acid hydrolysis of high-amylose corn starch. J. Appl. Glycoside. 60 (2), 123130 .

[26] Yu, H., Fang, Q., Cao, Y. and Liu, Z. (2016). Effect of HCl on starch structure and properties of starch-based wood adhesives. Journal of Bio. Resources, 11 (1), 1721-1728.

[27] Wang, X., et al (2017). Macromolecules Effect of acid hydrolysis on morphology, structure and digestion property of starch from Cynanchum auriculatum Royle ex Wight. International Journal of Biological Macromolecules. Elsevier B V., 96, 807-816.

[28] Jiang, M., et al (2017). Effects of acid hydrolysis intensity on the properties of starch/xanthan mixtures. International Journal of Biological Macromolecules. Elsevier, 106, 320-329.
[29] Li, D., et al (2017). Food Hydrocolloids Characterization of acid hydrolysis of granular potato starch under induced electric field. Food hydrocolloids. Elsevier Ltd, 71, 198-206.

[30] Genkina, N. K., Kiseleva, V. I. and Noda, T. (2009). Comparative investigation on acid hydrolysis of sweet potato starches with different amylopectin chain-length. Starch/Staerke, 61 (6), 321-325.

[31] Beninca, C., et al (2013). The thermal, rheological and structural properties of cassava starch granules modified with hydrochloric acid at different temperatures. Thermochimica Acta. 552, 65-69.

[32] Biliaderis, C. G., Grant, D. R. and Vose, J. R. (1981). Structural characterization of legume starches. II. Studies on acid-treated starches. Cereal Chem. 58, 502-507.

[33] Jiang, H., Srichuwong, S., Campbell, M. and Jane, J. L. (2010). Characterization of maize amylose-extender (ae) mutant starches. Part III: Structures and properties of the Naegeli dextrins. Carbohydr. Polym. 81, 885-891.

[34] Kim, H. Y., et al (2012). Characterization of nanoparticles prepared by acid hydrolysis of various starches. Starch/Staerke, 64 (5), 367-373.

[35] Le Corre D., Bras, J. and Dufresne, A. (2010). Starch nanoparticles: A review. Journal of Biomacromolecules. 11, 1139-1153.

[36] Wei, B. X., Hu, X. T., Zhang, B., Li, H. Y., Xu, X. M., Jin, Z. $Y$., et al (2013). Effect of defatting on acid hydrolysis rate of maize starch with different amylose contents". International Journal of Biological Macromolecules, 62, 652-656.

[37] Al-Rabadi, G. J. S., Gilbert, R. G. and Gidley, M. J. (2009). Effect of particle size on kinetics of starch digestion in milled barley and sorghum grains by porcine alpha-amylase. Journal of Cereal Science, 50 (2), 198-204.

[38] Blazek, J. and Gilbert, E. P. (2010). Effect of Enzymatic Hydrolysis on Native Starch Granule Structure. Biomacromolecules, 11 (12), 3275-3289.

[39] Lee, K. Y., Lee, S. and Lee, H. G. (2010). Effect of the Degree of Enzymatic Hydrolysis on the Physicochemical Properties and in vitro Digestibility of Rice Starch. 19 (5), 1333-1340.

[40] Foresti, M. L. (2011). Characterization of Chemically Modified Potato Starch Films Through Enzymatic Degradation. 2214, 217-224.

[41] Vrsalovic, A. (2013). Mathematical modelling of maize starch liquefaction catalysed by a-amylases from Bacillus licheniformis: effect of calcium, $\mathrm{pH}$ and temperature". 117126.

[42] Li, Z., et al (2015). The effect of starch concentration on the gelatinization and liquefaction of corn starch. Food Hydrocolloids, 48, 189-196.

[43] Xu, Q. S., Yan, Y. S. and Feng, J. X. (2016). Biotechnology for Biofuels Efficient hydrolysis of raw starch and ethanol fermentation: a novel raw starch-digesting glucoamylase from Penicillium oxalicum. Biotechnology for Biofuels. BioMed Central, 1-18.

[44] Council for Scientific and Industrial Research (CSIR)-Crops Research Institute (CRI), Ghana. CSIR Crop Varieties Released and Registered in Ghana report. 
[45] Dunsmore, B. A., Mellet, P. and Wolff, M. (1980). Some Factors Affecting the Lane and Eynon Titration Method for Determining Reducing. Proceedings of the South African Sugar Technology Assoc., (June), 0-4.

[46] Gandhi, Y. S., et al (2017). Reducing Sugar Determination of Jaggery by Classical Lane and Eynon Method \& 3, 5-Dinitrosalicylic Acid Method. Imperial Journal of Interdisciplinary Research, 3 (6), 2454-1362.

[47] Hermiati, E., et al (2012). Microwave-assisted Acid Hydrolysis of Starch Polymer in Cassava Pulp in the Presence of Activated Carbon. Procedia Chemistry. Elsevier, 4, 238-244.

[48] Khatoon, S., et al (2009). Properties of enzyme modified corn, rice and tapioca starches. Food Research International, 42 (10), $1426-1433$
[49] Shariffa, Y. N., et al (2009). Enzymatic hydrolysis of granular native and mildly heat-treated tapioca and sweet potato starches at sub-gelatinization temperature. Food Hydrocolloids. $23,434-440$.

[50] Sanchez de la Concha, B. B., et al (2018). Acid hydrolysis of waxy starches with different granule size for nanocrystal production. Journal of Cereal Science, 79, 193-200.

[51] Tester, R. F., et al (1995). Effects of elevated growth temperature and carbon dioxide levels on some physicochemical properties of wheat starch. Journal of Cereal Science. 22 (1), 63-71.

[52] Tester, R. F., Karkalas, J. and Qi, X. (2004). Starch-composition, fine structure and architecture. Journal of Cereal Science. Academic Press, 39 (2), 151-165. 